Mojca Leskovec

DOI: $10.4312 /$ vestnik.11.393-395

Filozofska fakulteta, Univerza v Ljubljani

Slovenija

mojca.leskovec@ff.uni-lj.si

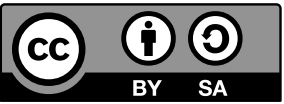

\title{
PRIMA LOS GEHT'S: DEUTSCH FÜR KINDER A1, BAND 1: SCHÜLERBUCH
}

Ciepielewska-Kaczmarek, Luiza/Obradović, Aleksandra/Sperling, Susanne/Valman, Giselle/Lundquist-Mog, Angelika (2018): prima Los geht's: Deutsch für Kinder A1, Band 1: Schülerbuch. Berlin: Cornelsen Verlag. ISBN: 978-3-06-520625-9, mehka vezava, 80 strani, $12,99 €$.

\section{Uvod}

Učno gradivo prima Los geht's za raven A1 poleg pregledanega učbenika, izdanega v letu 2018, ter delovnega zvezka s priloženo avdiozgoščenko in zvežčičem nalepk obsega še digitalni in tiskani priročnik za učitelja ter avdio- in videoposnetke k učbeniku. Na platformi Scook (https://www.scook.de/) je prav tako na voljo učbenik v e-obliki.

\section{Zgradba učnega gradiva}

Učbenik kot osnovno učno sredstvo sestavlja uvodna enota, ki z igro in pesmijo uvaja v učenje nemščine, osem nadaljnjih enot, vsaka z lastno temo, ter štiri mednje uvrščene dodatne enote, t. i. premori, namenjene ponovitvi prek igre in kratkih animacijskih filmov. Na zadnjih straneh učbenika najdemo gradiva za spoznavanje prazničnih običajev nemško govorečih dežel, abecedni seznam v učbeniku uporabljenih besed s pripisano enoto, nalogo in stranjo njihove prve pojavitve, pregled črk in glasov nemškega jezika ter pobarvanko z učbeniškimi figurami za izrez, namenjenimi igranju dialogov. Platnice učbenika ponujajo slikovni zemljevid nemško govorečih dežel ter pregled v učbeniku uporabljenih simbolov in navodil za delo.

Vsaka od osmih učbeniških enot obsega skupno šest strani, od tega pet strani obravnave nove snovi, ki se zaključi z miniprojektom, in zadnjo stran s pregledom pomembnih besednih zvez in struktur enote ter kratkim stripom. Vsako novo temo uvaja dvojna stran $\mathrm{z}$ navedenim naslovom enote in zastavljenimi učnimi cilji ter fotokolažem, ki upodablja zanimive kraje in srečanja $\mathrm{v}$ njih. 


\section{Vsebina učnega gradiva}

Osem osnovnih učbeniških enot, naslovljenih Ich und du, slov. Jaz in ti, Meine Freunde, slov. Moji prijatelji, Meine Schulsachen, slov. Moje šolske potreb̌̌čine, Meine Schule, slov. Moja šola, Meine Woche, slov. Moj teden, Das esse ich gern, slov. To rad/-a jem, Meine Familie, slov. Moja družina, in Mein Lieblingstier, slov. Moja najljubša žival, posega $\mathrm{k}$ temam osebne identitete in odnosov $\mathrm{z}$ drugimi, prostega časa in izobraževanja, vsakodnevnega življenja ter hrane in pijače, pri čemer v ospredje postavlja zanimanja ciljne skupine, opredeljene kot otroci v starosti od devet let dalje. Pri tem pa učno gradivo ne zapostavlja razvijanja sporazumevalne zmožnosti v nemščini kot tujem jeziku, temveč učenca kot uporabnika usposablja za naslednja dejanja: pozdraviti in posloviti se, predstaviti se in povedati, kaj rad počne, predstaviti prijatelje in njihove konjičke, vprašati koga po starosti, predstaviti svojo šolo in urnik svojih dejavnosti, predstaviti svoj jedilnik in naročiti sladoled, predstaviti svojo družino in opisati živali.

\section{Razvijanje sporazumevalne zmožnosti}

Celostno sporazumevalno zmožnost v nemščini uporabniki s primo Los geht's za raven A1 razvijajo z urjenjem receptivnih in produktivnih zmožnosti, tj. slušnega in bralnega razumevanja ter ustnega in pisnega izražanja, kot tudi z razvijanjem interakcije in medkulturne zmožnosti ter specifičnih jezikovnih zmožnosti. Skladno s ciljno skupino učno gradivo v ospredje postavlja urjenje slušnega razumevanja ter govornega izražanja in interakcije, učenci pa se vendarle srečujejo tudi s kratkimi nalogami bralnega razumevanja in tvorjenjem prvih zelo preprostih besedil s pomočjo vzorcev. Medkulturne zmožnosti učenec ne razvija le neposredno prek izbranih gradiv za spoznavanje nemško govorečih dežel in njihove kulture $\mathrm{v}$ dodatku na koncu učbenika, temveč ves čas posredno prek osrednjih učbeniških figur, svojih vrstnikov, Emila, Lukasa, Mie, Toma, Lotte, in psa Sockeja, saj jih spremlja pri njihovih dogodivščinah v šoli in prostem času.

\section{Metodično-didaktični pristop}

Učno gradivo prima Los geht's za raven A1 skladno s ciljno skupino dosledno upošteva načela zgodnjega učenja tujih jezikov. Receptivne in produktivne zmožnosti vpeljuje v zaporedju, ki velja za naravno usvajanje jezika, najprej torej slušno razumevanje, nato govorno izražanje, šele zatem pa tudi bralno razumevanje in končno pisno izražanje. Specifične jezikovne zmožnosti podpirajo splošne, in ne stojijo v ospredju; brez poudarka so, pogosto s posnemanjem, vpeljane najosnovnejše slovnične strukture, besedišče pa je omejeno na nabor, značilen za starost navedene ciljne skupine. Posebno pozornost učbenik posveča le urjenju ustrezne izgovarjave prek posnemanja.

Z gibanjem, igrami, likovnim izražanjem in petjem učno gradivo nagovarja vse čute ter uresničuje načeli celostnega učenja in igre. Edino, kar bi učnemu gradivu, namenjenemu učenju nemščine bodisi kot prvega bodisi kot drugega tujega jezika, vsaj za vstopno 
raven lahko očitali, je pomanjkljivo vključevanje načela raznojezičnosti - ciljna skupina ima, če ne drugega, namreč zanesljivo že izkušnje z učenjem prvega, tj. maternega jezika.

\section{Zaključek}

Ocenjujem, da uporabniki po predelanem prvem delu učnega gradiva prima Los geht's za raven A1 v nemščini kot tujem jeziku zmorejo razumeti in tvoriti prva zelo preprosta govorjena in pisana besedila, ki se nanašajo nanje in njihovo ožje okolje. Učno gradivo ponuja nabor za svojo ciljno skupino avtentičnih situacij, podpira njena zanimanja ter spretno izkoristi njeno vedoželjnost in veselje do učenja, hkrati pa z raznolikimi nalogami in dodatnimi gradivi omogoča tudi notranjo diferenciacijo. Pri tem ostaja pregledno in preprosto za uporabo ter tako učencu in učitelju prijazno. 